\title{
In vivo Antiinflammatory Potential of Leaf Extracts of Acacia auriculiformis Benth.
}

\author{
N. K. RANGRA*, S. SAMANTA AND K. K. PRADHAN \\ Department of Pharmaceutical Sciences \& Technology, Birla Institute of Technology, Mesra, Ranchi, Jharkhand-835 215 , India
}

Rangra et al.: Antiinflammatory activity of leaves extract of Acacia auriculiformis

\begin{abstract}
The prime objective of the present study was to evaluate the probable in vivo antiinflammatory potential of various extracts of the leaves of Acacia auriculiformis Benth. using carrageenan and formalin-induced inflammation in the rats. Thereafter gas chromatography-mass spectrometry analysis of the bioactive extract was performed to identify the compounds responsible for the antiinflammatory activity. The in vitro antioxidant potential was determined through 2,2-diphenyl-1-picrylhydrazyl scavenging assay, hydrogen peroxide scavenging assay and reducing power assay. Overall butanol and methanol leaf extracts showed significant antioxidant free radical scavenging activity. The methanol and petroleum ether leaf extracts at a dose of $400 \mathrm{mg} / \mathrm{kg}$ showed the highest percent inhibition of 84.88 and 82.12, respectively in the carrageenan-induced rat paw edema model, whereas, in formalin-induced rat paw edema model the chloroform and methanol leaf extracts showed the highest percent inhibition of 65.68 and 63.34 at a dose of $400 \mathrm{mg} / \mathrm{kg}$, respectively. In both the antiinflammatory models, indomethacin (standard, $40 \mathrm{mg} / \mathrm{kg}$ ) was used for comparison with test extracts. The gas chromatography-mass spectrometry analysis of bioactive butanol and methanol extracts showed the presence of compounds like sterols (stigmasterol, $\beta$-sitosterol and $\gamma$-sitosterol) and phenolic compounds (phenol, 2,4-bis(1,1-dimethylethyl),2,4-ditert-butylphenol), which could be responsible for the pharmacological activities observed. These in vitro and in vivo studies indicated that the antiinflammatory and antioxidant potential of the methanol leaf extract of Acacia auriculiformis Benth. could due to the presence of high phenolic and sterol content.
\end{abstract}

Key words: Antioxidant, antiinflammatory, GC-MS, Acacia auriculiformis leaf extracts

Over decades, medicinal plants have been reported to contribute raw materials for traditional (Ayurveda, Homeopathy, Unani, Siddha, and Chinese) as well as modern medicine system. The rural population of many developing countries still depend on herbal drugs for primary health care. The remedial prospective of herbal drugs rely on its form used i.e. whether whole plant, or parts of the plant, or extracts, or isolated bioactive phytoconstituents. Herbal medicines usually consist of parts of medicinal plants or crude plant extracts composed of several phytoconstituents, which frequently show a synergistic effect.

Inflammation is an immunobiological response of body towards irritation, infection, harmful stimuli, and injury of body cells or tissues. Main symptoms of inflammation are redness, heat, swelling, pain and even loss of function ${ }^{[1]}$. Inflammation may last for a shorter (acute) or a longer (chronic) duration. In the acute phase, the inflammation is distinguished by raised blood flow and vascular permeability with fluid, leukocytes and cytokine (inflammatory mediators) accumulation. Whereas in the chronic or subacute phase, inflammation is distinguished by the initiation of specific cellular and humoral immune response to pathogens at the place of tissue injury. At present steroids, and non-steroidal drugs and even some herbal drugs available are used to counteract inflammation by inhibiting the release of cyclooxygenase (COX) enzymes i.e. COX-1 and $\mathrm{COX}-2$, which produce prostaglandins, thromboxane, and other inflammatory mediators ${ }^{[2,3]}$.

Reactive oxygen species (ROS) like hydroxyl, peroxynitrite radicals and superoxide anion are earlier reported to be involved in the inflammation process. The excessive generation of ROS leads to cellular

This is an open access article distributed under the terms of the Creative Commons Attribution-NonCommercial-ShareAlike 3.0 License, which allows others to remix, tweak, and build upon the work non-commercially, as long as the author is credited and the new creations are licensed under the identical terms

Accepted 16 June 2019

Revised 19 March 2019

Received 31 October 2018

Indian J Pharm Sci 2019;81(4):709-719 
biomolecular injury to carbohydrate, lipids, proteins, and nucleic acids, leading to cell and tissue damage, which in succession initiates inflammation process ${ }^{[4,5]}$. Therefore, compounds with scavenging properties towards ROS might have therapeutic efficacy towards inflammation. But to discover and develop more effective and less toxic drugs have become a challenge for the pharmaceutical chemist. Medicinal plants appear to be potential source of new chemical entities with high efficacy.

Acacia auriculiformis A. Cunn. ex Benth. is an evergreen tree, which is distributed throughout India and other parts of the world. It is commonly known as "Australian acacia" a member of Mimosaceae or Fabaceae, usually found as ornamental shade tree having greenish-white shade clustered flowers; seen in roadsides and in parks. Traditionally it has been used in the treatment of rheumatism, sore eyes, aches, itching, and allergy ${ }^{[6]}$. Recently several reports showed various pharmacological activities like CNS depressant ${ }^{[7,8]}$, antimalarial ${ }^{[9]}$ antifilaria ${ }^{[10]}$, cestocidal $^{[11]}$, antimicrobial $^{[12]}$, antimutagenic ${ }^{[7]}$, antioxidant ${ }^{[13]}$, chemopreventive $^{[7]}$, spermicidal ${ }^{[14]}$, wound healing ${ }^{[15]}$, antidiabetic and hepatoprotective ${ }^{[16]}$. In addition, various phytochemical investigations revealed the presence of flavonoids, tannins and triterpenoidal saponin glycosides in different parts of this plant ${ }^{[17]}$.

Phenolic group-bearing compounds with one or more hydroxyl groups in an aromatic ring impart a broad range of pharmacological activities like antimutagenic, anticarcinogenic, antiinflammatory and antioxidant activities $^{[18,19]}$. Although, to the best of our knowledge, the leaves of Acacia auriculiformis Benth. have not been previously explored for in vivo antiinflammatory activity. Therefore, an attempt was made to mainly investigate and highlight the in vivo antiinflammatory potential of various extracts of $A$. auriculiformis leaf.

\section{MATERIALS AND METHODS}

\section{Plant materials:}

Leaves of $A$. auriculiformis (Mimosaceae) were collected from Jharkhand (India) in September 2017. The plant was identified a voucher specimen was deposited in the Botanical Survey of India, Kolkata India (CNH/Tech.II/2015/42/32111).

\section{Preparation of the plant extracts:}

The maceration process was used in the preparation of plant extract. Clean leaves were air-dried at room temperature and made in to a coarse powder. The dried powdered leaves of $A$. auriculiformis were defatted using petroleum ether and subsequently extracted using chloroform, ethyl acetate, acetone, butanol, and methanol. All the extracts were concentrated under vacuum and lyophilized separately for further use. The extraction yield was calculated for all the extracts which were, methanol (7.4 g), petroleum ether ( $4.1 \mathrm{~g})$, chloroform $(3.5 \mathrm{~g})$, ethyl acetate $(4.6 \mathrm{~g})$, n-butanol $(4.8 \mathrm{~g})$ and acetone $(3.2 \mathrm{~g})$.

\section{Preliminary phytochemical screening:}

The phytochemical analysis of all the leaf extracts was performed to detect the presence of various secondary metabolites like alkaloids (Dragendorff reagent, Mayer reagent test, Wagner reagent test, and Hager reagent test), steroids (Salkowski test, Libermann-Burchard test) flavonoids (Shinoda and alkaline reagent test), glycosides (sodium hydroxide reagent, Keller-Kiliani test), saponins (foam test), and tannins (chlorogenic test, catechin test and vanillin-hydrochloric acid test ${ }^{[20]}$. The detailed procedure of the above-performed tests is shown in Table 1.

\section{DPPH free radical scavenging assay:}

The antioxidant free radical scavenging activity for various leaf extracts towards stable 2,2-diphenyl1-picrylhydrazyl (DPPH) was carried out using the DPPH assay. The mechanism behind the antioxidant effect is hydrogen donating potential of the compound to the unstable radical form of DPPH. In this way, the radical form of DPPH is scavenged by an antioxidant leading to change in colour from purple to yellow. A gradual decrease in absorbance was measured at $517 \mathrm{~nm}$. With the modest change in procedure depicted by Kant et al., free radical scavenging potential of all the leaf test extracts was performed ${ }^{[21]}$. Stock solutions $(1 \mathrm{mg} / \mathrm{ml})$ of butylated hydroxytoluene (BHT), the standard and the test leaf extracts (methanol, petroleum ether, chloroform, ethyl acetate, butanol, and acetone) were prepared in ethanol. Test solutions were prepared by pipetting out $10,20,30,40$ and $50 \mu \mathrm{g} / \mathrm{ml}$ of BHT or the leaf extract aliquots from the stock solutions in test tube and the volumes were made up with ethanol. Thereafter the pipetted out aliquots were transferred to test tubes containing $2 \mathrm{ml}$ of the $0.1 \mathrm{mM} \mathrm{DPPH}$ solution prepared in ethanol. The mixture was allowed to stand for $30 \mathrm{~min}$ at $25^{\circ}$ after vigorous shaking. Gradual decrease in absorbance was observed on a UV spectrophotometer (Shimadzu 2450, Japan) at $517 \mathrm{~nm}$, when compared toblank, which was composed of 


\begin{tabular}{|c|c|c|}
\hline Test & Procedure & Inference \\
\hline Dragendorff's reagent test & $\begin{array}{l}\text { Extract }(2 \mathrm{mg})+\text { distilled water }(5 \mathrm{ml})+\mathrm{HCl} \\
(1 \mathrm{ml})+\text { Dragendorff's reagent }(1 \mathrm{ml})\end{array}$ & Orange/orange red precipitates \\
\hline Mayer reagent test & Extract (2 mg)+Mayer's reagent (few drops) & White/pale yellow precipitates \\
\hline Wagner reagent test & $\begin{array}{c}\text { Extract }(2 \mathrm{mg})+\mathrm{HCl}(1.5 \% \mathrm{vv})+\text { Wagner's reagent } \\
\text { (few drops) }\end{array}$ & Yellow/brown precipitates \\
\hline Hager reagent test & Extract (2 mg)+Hager's reagent (few drops) & Yellow precipitates \\
\hline Salkowski test & $\begin{array}{c}\text { Dry extract }(2 \mathrm{mg}) \text { shaken with chloroform }+\mathrm{H}_{2} \mathrm{SO}_{4} \text { added } \\
\text { to chloroform layer }\end{array}$ & Formation of red colour \\
\hline Libermann-Burchard test & $\begin{array}{c}\text { Dry extract }(2 \mathrm{mg}) \text { dissolved in acetic anhydride+heated } \\
\text { to boiling+cooled+concentrated } \mathrm{H}_{2} \mathrm{SO}_{4}(1 \mathrm{ml})\end{array}$ & Formation of green colour \\
\hline Shinoda test & $\begin{array}{c}\text { Extract }(2 \mathrm{mg}) \text { dissolved in } 5 \mathrm{ml} \text { of ethanol }+10 \text { drops of } \\
\text { dilute } \mathrm{HCl}+\text { small piece of magnesium }\end{array}$ & $\begin{array}{l}\text { Formation of pink, reddish or } \\
\text { brown colour }\end{array}$ \\
\hline Alkaline reagent test & Test solution+NaOH solution (few drops) & $\begin{array}{l}\text { Formation of intense yellow } \\
\text { colour turns to colourless with } \\
\text { dilute acetic acid addition }\end{array}$ \\
\hline Sodium hydroxide reagent test & $\begin{array}{c}\text { Extract }(5 \mathrm{mg}) \text { dissolved in } 0.5 \mathrm{ml} \text { of } 20 \% \mathrm{H}_{2} \mathrm{SO}_{4} \\
\text { solution+ }+\mathrm{NaOH} \text { solution (few drops) }\end{array}$ & Formation of blue colour \\
\hline Keller-Kiliani test & $\begin{array}{l}\text { Extract }(1 \mathrm{ml}) \text { boiled with } 10 \mathrm{ml} \text { of } 70 \% \text { alcohol for } 2-3 \\
\text { min and filtered } \\
\text { filtrate+water }(5 \mathrm{ml})+\text { lead acetate }(0.5 \mathrm{ml})+\text { shaken well } \\
\text { filtrate (clear)+chloroform evaporated to extractives } \\
\text { extractives+glacial acetic acid }+\mathrm{FeCl}_{3} \text { solution } \\
\qquad(2 \text { drops })+\mathrm{H}_{2} \mathrm{SO}_{4} \text { solution }(2 \mathrm{ml})\end{array}$ & $\begin{array}{l}\text { Formation of bluish green colour } \\
\text { from reddish brown layer on } \\
\text { standing }\end{array}$ \\
\hline Foam test & $\begin{array}{l}\text { Extract solution }(1 \mathrm{ml})+\text { distilled water }(20 \mathrm{ml})+\text { shaken } \\
\text { for } 15 \mathrm{~min}\end{array}$ & Formation of stable foam \\
\hline $\begin{array}{l}\text { Catechin test } \\
\text { (Match stick test) }\end{array}$ & $\begin{array}{c}\text { Match stick dipped in aqueous extract and dried near } \\
\text { burner and moistened with } \mathrm{HCl}\end{array}$ & $\begin{array}{c}\text { Matchstick wood turns pink } \\
\text { or red due to formation of } \\
\text { phloroglucinol }\end{array}$ \\
\hline Chlorogenic test & Extract solution+aqueous ammonia & Green colour on exposure to air \\
\hline Vanillin-hydrochloric acid test & $\begin{array}{l}\text { Extract solution+vanillin-hydrochloric acid reagent }(1 \mathrm{~g} \\
\text { vanillin+10 } \mathrm{ml} \text { alcohol }+10 \mathrm{ml} \text { concentrated } \mathrm{HCl})\end{array}$ & $\begin{array}{l}\text { Pink or red colour formed } \\
\text { due to formation of } \\
\text { phloroglucinol }\end{array}$ \\
\hline
\end{tabular}

$300 \mu \mathrm{l} / \mathrm{ml}$ of ethanol in $2 \mathrm{ml}$ of DPPH solution. Triplicate measurements were performed. Percent inhibition of free radical DPPH was calculated using the Eqn., I \% = $(\mathrm{Ab}-\mathrm{As} / \mathrm{Ab}) \times 100$, where $\mathrm{Ab}$ is the absorbance of the control reaction and As is the absorbance of the test compound.

\section{Hydrogen peroxide scavenging assay:}

The hydrogen peroxide scavenging assay for various leaf extracts was performed according to the procedure stated by Dey et al. with little modifications ${ }^{[22]}$. The standard (BHT) and test leaf extracts of A. auriculiformis having concentrations 10, 20, 30, 40, $50 \mu \mathrm{g} / \mathrm{ml}$ were prepared in Mili-Q water. Hydrogen peroxide $(2 \mathrm{M}, 2.5 \mathrm{ml})$ in phosphate buffer $(0.2 \mathrm{M}$, $\mathrm{pH}$ 7.4) was blended with $1.5 \mathrm{ml}$ test leaf extract and standard (BHT). The mixture was shaken and incubated for 10 min away from light and absorbance was recorded at $230 \mathrm{~nm}$. The blank solution used in the above study was phosphate buffer without hydrogen peroxide. Triplicate measurements were performed. Percent inhibition of hydrogen peroxide scavenging activity was calculated using the Eqn., I \% $=(\mathrm{Ab}-\mathrm{As} /$ $\mathrm{Ab}) \times 100$, where $\mathrm{Ab}$ is the absorbance of the control reaction and As is the absorbance of the test compound.

\section{Reducing power assay:}

The reducing power assay for different leaf test extracts of $A$. auriculiformis was carried out according to the procedure stated by Dey et al. with slight changes ${ }^{[22]}$. The standard (BHT) and test leaf extracts of A. auriculiformis having concentrations 10, 20, 30, 40, $50 \mu \mathrm{g} / \mathrm{ml}$ were prepared in Mili-Q water. One milliliter of test extract solution was mixed with $2.5 \mathrm{ml}$ of $0.2 \mathrm{M} \mathrm{KH}_{2} \mathrm{PO}_{4}$ buffer solution having $\mathrm{pH} 6.6$ and $2.5 \mathrm{ml}$ of $\mathrm{K}_{3}\left[\mathrm{Fe}(\mathrm{CN})_{6}\right]$. This reaction mixture was allowed to stand for $20 \mathrm{~min}$ and subjected to treatment for the temperature of $50^{\circ}$. The reaction blend was cooled and trichloroacetic acid $(2.5 \mathrm{ml}$ of $10 \%)$ was added followed by the centrifugation for $10 \mathrm{~min}$ at $2000 \mathrm{rpm}$. Thereafter $2.5 \mathrm{ml}$ of the upper centrifuged layer was considered and $\mathrm{FeCl}_{3}$ solution $(0.5 \mathrm{ml}$ of $0.1 \%$ ) and Mili-Q water $(2.5 \mathrm{ml})$ was added to it. Absorbance was measured at $700 \mathrm{~nm}$ using UV 
spectrophotometer. The control solution was prepared in a likely way (as described above) without considering the test leaf extracts. Triplicate measurements were performed. Percent inhibition of reducing power assay was calculated using the Eqn., I \% $=(A b-A s / A b) \times 100$, where $\mathrm{Ab}$ is the absorbance of the control reaction and As is the absorbance of the test compound.

\section{Experimental animals:}

Wistar rats weighing between 150-220 g were used in these studies. Rats were maintained in the standard experimental laboratory animal house (conditions at $25 \pm 2^{\circ}, 50 \pm 15 \% \mathrm{RH}$ and normal photoperiod $12 \mathrm{~h}$ dark/12 h light) in the Department of Pharmaceutical Sciences and Technology, Birla Institute of Technology, Mesra, India. To all animals, water and commercial pellet diet were provided ad libitum. The animal experimental protocol was approved by Institutional Animal Ethics Committee (IAEC) with the protocol number PROV/BIT/PH/IAEC/08/2016.

\section{Acute toxicity study:}

The acute toxicity study was carried out according to the Organisation for Economic Co-operation and Development (OECD) guidelines 425 (acute oral toxicity: Up-and-Down Procedure) ${ }^{[23]}$. Wistar rats (150$200 \mathrm{~g}$ ) of either sex were used for this study. Five rats were chosen for animal studies. Animals were fasted overnight and extracts were given orally at a single dose of $2000 \mathrm{mg} / \mathrm{kg}$. Mortality, abnormal behavior and any physical lesions were studied for $14 \mathrm{~d}$.

\section{Carrageenan-induced rat paw edema assay:}

Leaf extract samples were screened for in vivo antiinflammatory studies using a slightly modified carrageenan-induced rat paw edema model as described earlier ${ }^{[24]}$. In the right hind paw of ether anesthetized rat, edema was induced by subplantar injection of $0.1 \mathrm{ml}$ carrageenan $(1 \% \mathrm{w} / \mathrm{v})$ in $0.9 \%$ saline. One hour before carrageenan injection, test samples (prepared in $1 \%$ $\mathrm{w} / \mathrm{v}$ gum acacia) were administred orally (po) at a dose of 200 and $400 \mathrm{mg} / \mathrm{kg}$. Indomethacin (40 mg/kg, po) was used as the standard while the control group was administered vehicle only. Using a plethysmometer (Samitek Instrument) thickness of the paw was measured immediately before injecting the carrageenan at $0 \mathrm{~h}$ and at 2, 4, and $6 \mathrm{~h}$ after carrageenan injection. From 0 to $6 \mathrm{~h}$ the increase in paw thickness measurement was observed and expressed as a difference in paw thickness. Percent inhibition in volume was shown as a value with respect to the control group at various time spans. \% Inhibition $=(1-$ difference in paw volume of treatment/difference in paw volume of control) $\times 100$.

\section{Formalin-induced paw edema in the rat:}

Antiinflammatory activity of leaf extracts was tested using slightly modified and earlier described formalininduced paw edema model ${ }^{[25]}$. The $0.05 \mathrm{ml}$ of $2.5 \%$ formalin was injected into the sub-plantar region of the right hind paw of ether anesthetized rat. All test leaf extracts (200 and $400 \mathrm{mg} / \mathrm{kg}$ ), standard indomethacin (40 mg/kg) and saline $2 \mathrm{ml} / \mathrm{kg}$ were administered orally (po) $1 \mathrm{~h}$ before formalin injection and at next 6 consecutive $\mathrm{h}$ using an oral gavage needle. The elevated paw edema was measured using a plethysmometer. The paw thickness was measured just prior to formalin injection i.e. $0 \mathrm{~h}$ and at 2, 4, and $6 \mathrm{~h}$ after formalin injection, using a plethysmometer. From 0 to $6 \mathrm{~h}$, rise in paw thickness measurement was observed as a difference in paw thickness. Percent inhibition in volume was expressed as a value with respect to the control group at various time intervals. \% Inhibition $=(1-$ difference in paw volume of treatment $/$ difference in paw volume of control $) \times 100$.

\section{Statistical evaluation of data:}

Results of in vivo antiinflammatory activity were expressed as the mean $\% \pm \operatorname{SEM}$ (standard error of mean) of $n=6$ animals. The statistical differences between the test or treated and control groups were analyzed through one way ANOVA (SPSS version 9.05) followed by Dunnett's test application. In statistical analysis, the values having $\mathrm{p}<0.05$ were regarded as significant.

Gas chromatography-mass spectroscopy (GC-MS) analysis of the bioactive extracts:

The GC-MS analysis of butanol and methanol leaf extracts was performed using GC-MS instrument (Thermo Scientific Co., Thermo GC-TRACE ultra ver.:5.0, Thermo MS DSQ II). The experimental conditions maintained during analysis in the instrument were as follows, HP 5-MS capillary standard non-polar column was used having dimensions $30 \mathrm{~m}$ length, $0.25 \mathrm{~mm}$ diameter and the film thickness of $0.25 \mu \mathrm{m}$. The mobile phase used was pure helium (He, carrier gas) having $99.995 \%$ purity and flow rate fixed at $1 \mathrm{ml} / \mathrm{min}$. The oven temperature in GC was elevated from $80^{\circ}$ to $280^{\circ}$ at the rate of $5^{\circ}$ and the injection volume was set at $1 \mu 1$. The butanol and methanol test extract samples were dissolved in chloroform and run at a range of $50-650 \mathrm{~m} / \mathrm{z}$. The Wiley spectral library search programme was used to compare the results. 


\section{RESULTS AND DISCUSSION}

The qualitative preliminary phytochemical screening test results of leaf extracts (Table 2) revealed the presence of secondary metabolic constituents like phenolic content, flavonoids, saponins, tannins, and glycosides.

The in vitro DPPH scavenging assay results (fig. 1A) revealed significant activity in butanol, ethyl acetate, acetone, and methanol leaf extracts. The butanol, ethyl acetate, acetone, and methanol leaf extracts showed 74.27, 63.66, 60.05, and 53.05\% inhibition of paw volume, respectively at $20 \mu \mathrm{g} / \mathrm{ml}$ as compared to standard (BHT), which showed an inhibition of $97.29 \%$ at $40 \mu \mathrm{g} / \mathrm{ml}$. The highest percent inhibition of 98.42 was shown by the butanol leaf extract at $50 \mu \mathrm{g} / \mathrm{ml}$ as compared to BHT, which showed $97.52 \%$ inhibition at $50 \mu \mathrm{g} / \mathrm{ml}$ concentration. The petroleum ether and chloroform leaf extracts showed relatively lower percent inhibition of 82.17 and 62.11 at $40 \mu \mathrm{g} / \mathrm{ml}$ as compared to other leaf extracts.

The measurable aspect of the DPPH free radical scavenging assay is a change in color from purple to yellow when the antioxidant reacted with DPPH. The prominence of the antioxidant action lies in the intense color change from purple to yellow. The reason behind this phenomenon is the formation of a stable complex due to the reaction between the antioxidant and DPPH. Polyphenolic compounds are reported to possess potent antioxidant activity ${ }^{[26]}$. Among the tested leaf extracts, butanol leaf extract showed the highest significant DPPH scavenging activity followed by ethyl acetate, acetone, and methanol leaf extracts at a concentration of $20 \mu \mathrm{g} / \mathrm{ml}$. The order of activity of other extracts tested was found to be in the order: butanol<ethyl acetate $<$ acetone $<$ methanol $<$ chloroform $<$ pet ether. This could be due to the presence of high flavonoid content in these extracts. The high amount of phenolics and tannins is also responsible for imparting significant reducing activity of the above extracts.

The in vitro $\mathrm{H}_{2} \mathrm{O}_{2}$ scavenging assay results shown in fig. 1B revealed significant activity in the methanol, acetone, butanol and ethyl acetate extracts of the leaves as compared to BHT, the standard used. Percent inhibition shown by methanol and acetone extracts at $20 \mu \mathrm{g} / \mathrm{ml}$ were 61.25 and 50.05 , respectively when compared to BHT, which showed a percent inhibition of 51.53 at $20 \mu \mathrm{g} / \mathrm{ml}$. The butanol and ethyl acetate extracts at $30 \mu \mathrm{g} / \mathrm{ml}$ showed percent inhibition of 65.09 and 60.03 , respectively as compared to the standard, which showed $66.48 \%$ inhibition at $30 \mu \mathrm{g} / \mathrm{ml}$. The highest inhibition of $93.94 \%$ was shown by the methanol extract at $50 \mu \mathrm{g} / \mathrm{ml}$ dose, while the standard showed $98.43 \%$ inhibition at the same concentration. The petroleum ether $(72.07 \%)$ and chloroform (52.01\%) extracts showed relatively lower activity at $40 \mu \mathrm{g} / \mathrm{ml}$ as compared to other leaf extracts.

Hydrogen peroxide is known as a weak oxidizing agent, which denatures enzymes directly by oxidizing the important thiol groups. It is highly light sensitive and quickly enters the cell through cell membranes and reacts with $\mathrm{Fe}^{2+}$ and $\mathrm{Cu}^{2+}$ ions to form hydroxyl radicals $^{[22]}$. The methanol extracts showed the highest activity among all the tested extracts at a concentration of $20 \mu \mathrm{g} / \mathrm{ml}$ as compared to BHT. The activity of other extracts in a concentration-dependent manner was found to be in the order, methanol $<$ acetone $<$ butanol $<$ ethyl acetate $<$ chloroform $<$ petroleum ether. The hydrogen donating potential of phenolic constituents present in the extracts appeared to be responsible for scavenging of hydroxyl radicals.

The in vitro reducing power assay results (fig. 1C) disclosed significant activity of the ethyl acetate, acetone, methanol, and chloroform extracts as compared to BHT. Percent inhibition shown by ethyl acetate and acetone extracts at $20 \mu \mathrm{g} / \mathrm{ml}$ dose were,

TABLE 2: QUALITATIVE PHYTOCHEMICAL SCREENING OF DIFFERENT LEAF EXTRACTS OF ACACIA AURICULIFORMIS

\begin{tabular}{|c|c|c|c|c|c|c|}
\hline \multirow{2}{*}{ Phytochemical tests } & \multicolumn{6}{|c|}{ Leaf extracts } \\
\hline & Pet. ether & Chloroform & Ethyl acetate & n-Butanol & Acetone & Methanol \\
\hline Alkaloids & ++ & + & - & +++ & + & + \\
\hline Flavonoids & - & - & +++ & +++ & +++ & +++ \\
\hline Steroids & +++ & ++ & + & + & + & + \\
\hline Tannins & - & + & ++ & ++ & +++ & ++ \\
\hline Glycosides & - & + & +++ & +++ & ++ & +++ \\
\hline Saponins & - & + & ++ & +++ & +++ & ++ \\
\hline
\end{tabular}

'+' Slightly present, '++' moderately present, '+++' highly present, '-' absent 


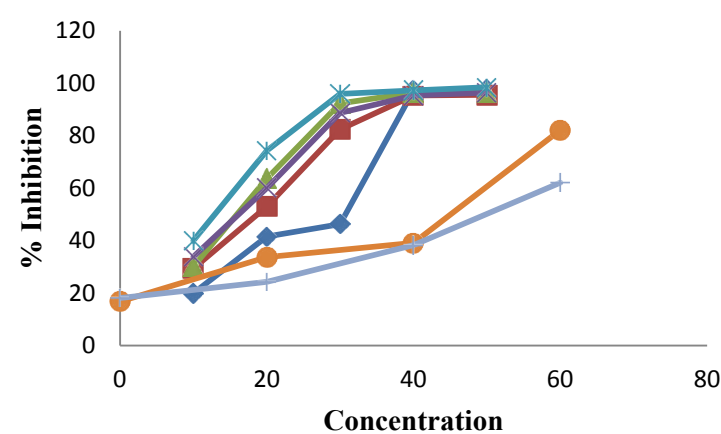

A

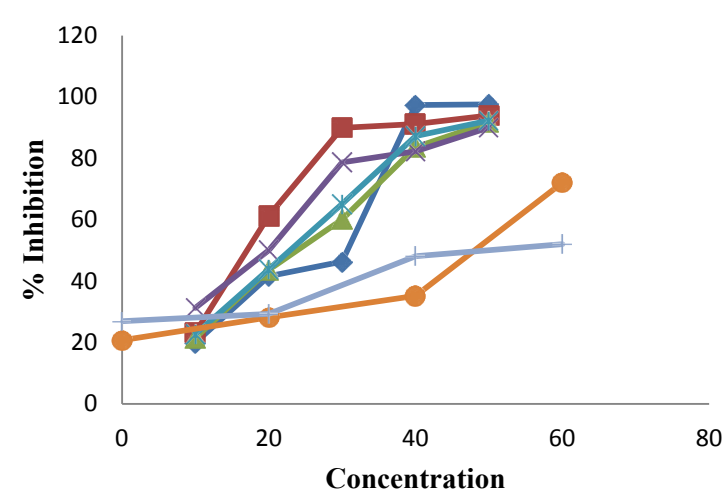

B

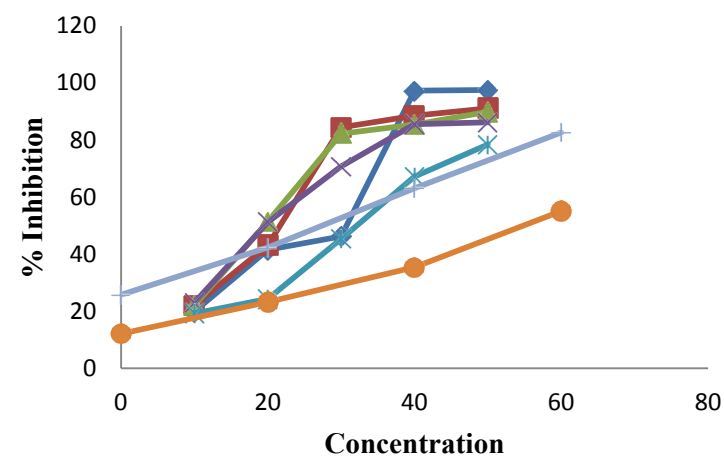

C

Fig. 1: Antioxidant effects of leaf extracts of Acacia auriculiformis

(A) DPPH free radical scavenging assay, (B) hydrogen peroxide $\left(\mathrm{H}_{2} \mathrm{O}_{2}\right)$ scavenging assay and $(\mathrm{C})$ reducing power assay. $\%$ inhibition BHT; - - \% inhibition methanol extract; $-\triangle-\%$ inhibition ethyl acetate extract; $-\times-\%$ inhibition acetone extract; $-*-\%$ inhibition butanol extract; $-0-$ $\%$ inhibition petroleum ether extract; $-I-\%$ inhibition chloroform extract

51.44 and 51.25, respectively, whereas BHT showed of $56.68 \%$ inhibition at $30 \mu \mathrm{g} / \mathrm{ml}$. The highest percent inhibition of 91.09 was shown by methanol extract at $50 \mu \mathrm{g} / \mathrm{ml}$ while the standard showed $97.92 \%$ inhibition at the same concentration. The methanol and chloroform extracts showed inhibition of 84.41 and $63.12 \%$, respectively at $30 \mu \mathrm{g} / \mathrm{ml}$. The petroleum ether $(55.12 \%)$ and butanol $(67.21 \%)$ leaf extracts showed low activity at $40 \mu \mathrm{g} / \mathrm{ml}$ as compared to other leaf extracts.
The basic principle behind the reducing power assay is the conversion of $\mathrm{Fe}^{3+}$ ion in $\mathrm{FeCl}_{3}$ to $\mathrm{Fe}^{2+}$ in presence of reducer antioxidant agents. The elevation in the absorbance of the reaction blend increases the antioxidant activity ${ }^{[22]}$. The ethyl acetate leaves extract showed the highest significant activity among all the tested leaf extracts at a concentration of $20 \mu \mathrm{g} / \mathrm{ml}$ as compared to standard (BHT). The order of activity of other leaf extracts in concentrationdependent manner was found to be in the order: ethyl $\quad$ acetate $<$ acetone $<$ methanol $<$ chloroform $<$ pet ether $<$ butanol. This may be due to the presence of reductones or antioxidants in the test leaf extracts, which cause reduction of ferric ion or ferric cyanide complex to ferrous ion form.

The acute toxicity study demonstrated that the extracts tested up to a dose of $2000 \mathrm{mg} / \mathrm{kg}$ (po, single dose) in rats and observed for $14 \mathrm{~d}$ showed no mortality, no abnormal behavior and physical lesions. So, the tested leaf extract of plant $A$. auriculiformis were found to be safe up to the dose of $2000 \mathrm{mg} / \mathrm{kg}$. On the basis of this toxicity study as well as reported studies, the doses of 200 and $400 \mathrm{mg} / \mathrm{kg}$ were selected.

After an exhaustive literature survey, it is possible to conclude that for the very first time, the in vivo antiinflammatory evaluation of the various leaf extracts of A. auriculiformis is being reported. The antiinflammatory activity of different $A$. auriculiformis leaf extracts were studied in carrageenan-induced rat paw edema model. The methanol and petroleum ether extracts administered orally at a dose of $400 \mathrm{mg} / \mathrm{kg}$ showed the highest percent inhibition (fig. 2A) of 84.88 and 82.12 , respectively. Comparison was made with the standard drug, indomethacin $(40 \mathrm{mg} / \mathrm{kg})$, which showed a percent inhibition of 94.01 at a dose of $40 \mathrm{mg} / \mathrm{kg}$. At $0 \mathrm{~h}$ just before the injection of carrageenan, the range of basal values was observed to be $1.22 \pm$ $0.86 \mathrm{ml}$ in control and in the inflammation control $1.21 \pm 0.47 \mathrm{ml}$. Whereas the paw volumes of rats treated with $400 \mathrm{mg} / \mathrm{kg}$ of the methanol extract were $1.15 \pm$ $0.88 \mathrm{ml}$ at the $0 \mathrm{~h}, 2.02 \pm 0.42 \mathrm{ml}$ at $2 \mathrm{~h}, 1.96 \pm 0.23 \mathrm{ml} 4 \mathrm{~h}$ and $1.30 \pm 0.12 \mathrm{ml}$ at $6 \mathrm{~h}$. The difference in paw volume between 0 and $6 \mathrm{~h}$ was found to be $0.15 \pm 0.001 \mathrm{ml}$ and the percent inhibition was 84.88 . The other extracts i.e. methanol, acetone, ethyl acetate, chloroform, butanol, and petroleum ether at a dose of $200 \mathrm{mg} / \mathrm{kg}$ showed percent inhibitions of 76.90, 62.01, 60.99, 66.81, 43.40, and 70.12, respectively. Whereas the acetone, ethyl acetate, chloroform, and butanol extracts at a 
dose of $400 \mathrm{mg} / \mathrm{kg}$ showed percent inhibition of 77.65, $60.02,67.12$, and 64.86 , respectively.

The carrageenan-induced rat paw edema model revealed the efficacy of methanol leaves extract at $400 \mathrm{mg} / \mathrm{kg}$ when compared to the standard drug indomethacin $(40 \mathrm{mg} / \mathrm{kg})$. The decrease in paw volume or decrease in paw edema was considered an effective antiinflammatory action. All the values were represented as mean $\% \pm$ SEM and $n=6$; whereas the values with $\mathrm{p}<0.05$ were considered to be significant (fig. 2B). The different extracts were found effective against carrageenan-induced paw edema in rats after $6 \mathrm{~h}$ as compared to inflammation control treated group. Methanol and petroleum ether extracts at the dose of $400 \mathrm{mg} / \mathrm{kg}$ were found to be the most effective $(\mathrm{p}<0.05)$.

The antiinflammatory effect of different leaf extracts of $A$. auriculiformis on the paw edema induced by the formalin method was also studied. The chloroform and methanol extracts showed the highest percent inhibition (fig. 3A) of 65.68 and 63.34 at a dose of $400 \mathrm{mg} / \mathrm{kg}$, po, respectively when compared to the standard drug indomethacin, which showed a percent inhibition of 76.81 at a dose of $40 \mathrm{mg} / \mathrm{kg}$. At $0 \mathrm{~h}$ just before the injection of carrageenan, the range of basal values was observed to be $1.22 \pm 0.86 \mathrm{ml}$ in normal control and in inflammation control $1.14 \pm 0.30 \mathrm{ml}$. In the $400 \mathrm{mg} / \mathrm{kg}$ chloroform extract treated group the paw volume values were $1.07 \pm 0.23 \mathrm{ml}$ at $0 \mathrm{~h}, 1.69 \pm 0.35 \mathrm{ml}$ at $2 \mathrm{~h}, 1.96 \pm 0.28 \mathrm{ml}$ at $4 \mathrm{~h}$ and $1.43 \pm 0.28 \mathrm{ml}$ at $6 \mathrm{~h}$. The difference in paw volume between 0 and $6 \mathrm{~h}$ was found to be $0.36 \pm 0.002 \mathrm{ml}$ and percent inhibition was 65.68 . The methanol, acetone, ethyl acetate, chloroform, butanol, and petroleum ether extracts at a dose of $200 \mathrm{mg} / \mathrm{kg}$ showed percent inhibition of $56.11,40.73$, $39.80,45.60,35.02$, and 37.12, respectively, while the acetone, ethyl acetate, butanol, and petroleum ether extracts at a dose of $400 \mathrm{mg} / \mathrm{kg}$ showed percent inhibition of 52.62, 52.98, 43.71, and 45.43, respectively.

The formalin-induced rat paw edema model used for in vivo antiinflammatory evaluation results showed that of all the leaf extracts tested, the methanol extract at a dose of $400 \mathrm{mg} / \mathrm{kg}$ was found to be significant when compared to the standard indomethacin $(40 \mathrm{mg} / \mathrm{kg})$. All results for statistical evaluation were presented as mean $\% \pm$ SEM of $n=6$ and the probability level with $\mathrm{p}<0.05$ was considered to be significant (fig. 3B). Different extracts were found to be effective

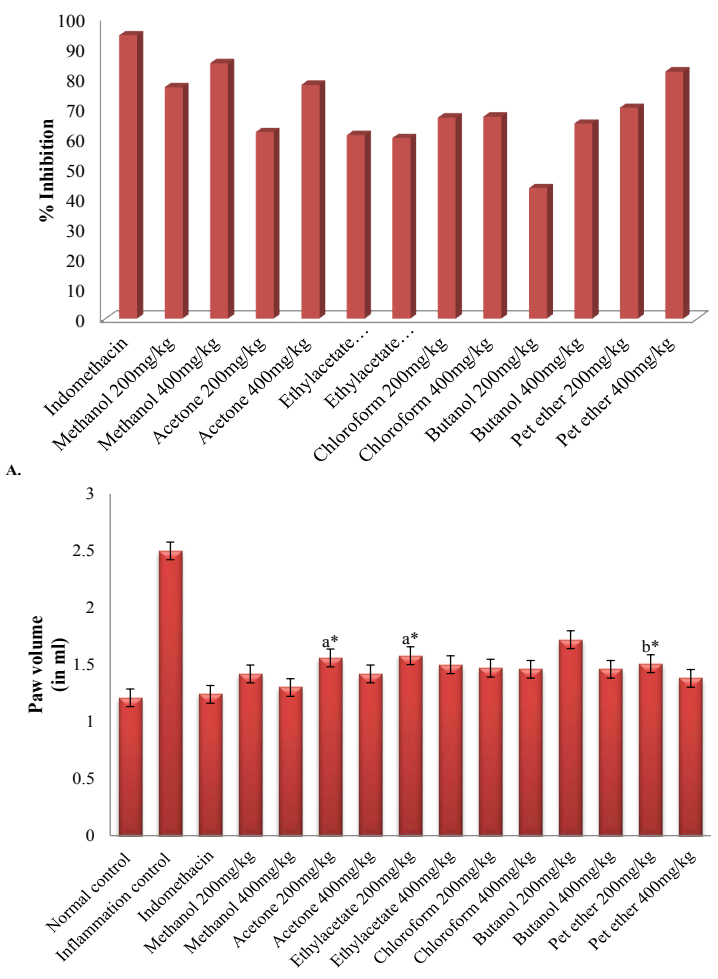

Fig. 2: Antiinflammatory effects of leaf extract of Acacia auriculiformis in rat carrageenan-induced paw edema model Values are expressed as mean \pm SEM of $n=6$. $p<0.05$ was considered to be significant. $a$ is $v s$ inflammation control; * $p<$ 0.05
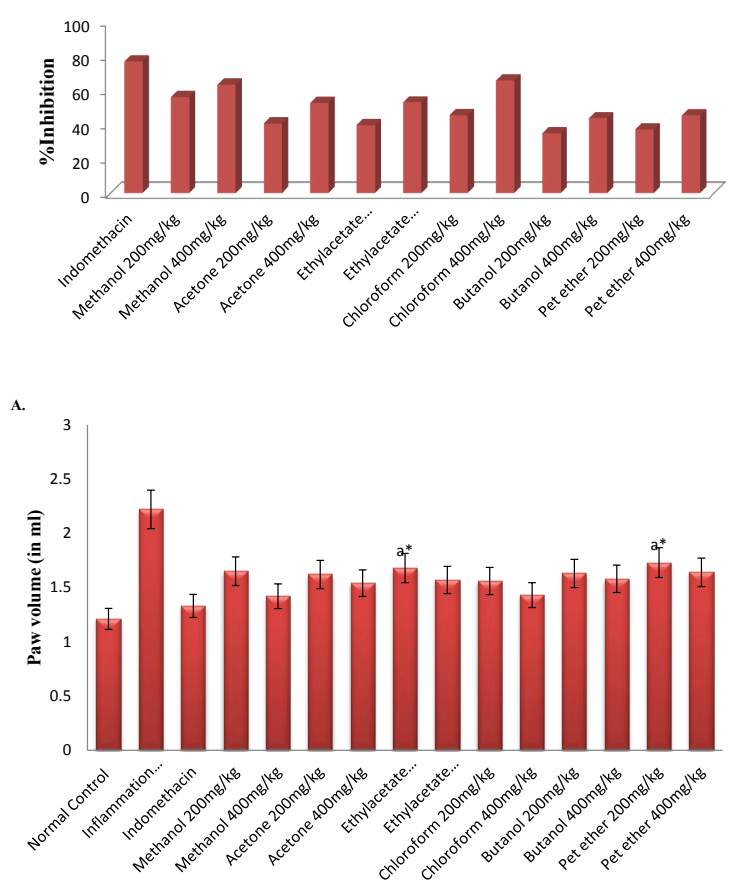

Fig. 3: Antiinflammatory effects of leaf extract of Acacia auriculiformis in formalin-induced paw edema in rats Values are expressed as mean \pm SEM of $n=6$. $p<0.05$ was considered to be significant. a is $v s$ inflammation control; ${ }^{*} \mathbf{p}<\mathbf{0 . 0 5}$ 
against formalin-induced paw edema in rats after $6 \mathrm{~h}$ as compared to inflammation in control rats. The chloroform extract at $400 \mathrm{mg} / \mathrm{kg}$ and methanol extract at $400 \mathrm{mg} / \mathrm{kg}$ were found to be most effective. The maximum antiinflammatory activity was observed at $400 \mathrm{mg} / \mathrm{kg}$ dose.

The carrageenan-induced rat paw edema and formalininduced paw edema models were considered to be effective models for the evaluation of antiinflammatory action. The inflammation is generally considered to be biphasic. The first phase lasted up to one hour and included secretion of histamine and serotonin whereas after one hour the second phase was initiated with the release of kinins, prostaglandins and other COX products. Bradykinin maintained the continuity between the two phases ${ }^{[27]}$. The standard drug indomethacin inhibited COX enzyme. The methanol extract exhibited a dose-dependent inhibitory effect similar to indomethacin in both the antiinflammatory models employed. The methanol extract at $400 \mathrm{mg} / \mathrm{kg}$ was found to be effective in both the models. This could be due to the presence of high levels of phenolic, flavonoid and sterol content in this extract, which led to antioxidant action ${ }^{[28]}$. Therefore, it could be noted that the antiinflammatory action of $A$. auriculiformis leaf extracts during the first and second phase of inflammation was due to the inhibition of COX, an enzyme necessary for the release of inflammatory mediators like prostaglandins, histamine, serotonin, bradykinin, and metabolism of arachidonic acid ${ }^{[29]}$. Selvam and Jachak reported that the carrageenan and formalin-induced paw edema models were more effective in evaluating the COX enzyme inhibition activity ${ }^{[30]}$. The Acacia genus has already been explored extensively for antiinflammatory activity ${ }^{[31-33]}$. On the basis of the above-reported evidence, it could be concluded that the antiinflammatory action of A. auriculiformis extract on the carrageenan and formalin-induced paw edema models could be mediated by the inhibition of COX enzyme.

The phytoconstituents present in methanol and butanol extract of $A$. auriculiformis are shown in Tables 3 and 4. The elution order and retention time were the basis of identifying the bioactive compounds. The peak retention time, peak area, percent peak area, peak height and percent peak height were presented. Based on the retention time, the major phytoconstituents present

TABLE 3: COMPOUNDS IDENTIFIED THROUGH GC-MS ANALYSIS OF BUTANOL EXTRACT OF ACACIA AURICULIFORMIS

\begin{tabular}{|c|c|c|c|c|c|c|c|}
\hline Peak & Name & Retention time & Area & Area (\%) & Height & Height (\%) & Base $(m / z)$ \\
\hline 1 & Phenol, 2,4-bis(1,1-imethylethyl) & 15.597 & 5650693 & 5.96 & 1585685 & 9.58 & 191.15 \\
\hline 2 & (E)-9-octadecene & 17.564 & 339115 & 0.36 & 141000 & 0.85 & 55.05 \\
\hline 3 & 3-Hydroxy-B-damascone & 18.023 & 921425 & 0.76 & 207644 & 1.25 & 69.05 \\
\hline 4 & Megastigmatrienone & 18.333 & 652090 & 0.69 & 228290 & 1.38 & 133.10 \\
\hline 5 & $\begin{array}{l}\text { 2-(3-Isopropyl-4-methyl-pent-3-en-1-ynyl)-2- } \\
\text { methyl-cyclobutanone }\end{array}$ & 22.642 & 1185064 & 1.25 & 348995 & 2.11 & 147.10 \\
\hline 6 & $\begin{array}{l}\text { 7,9-Di-tert-butyl-1-oxaspiro(4,5)deca-6,9- } \\
\text { diene-2,8-dione }\end{array}$ & 24.272 & 395711 & 0.42 & 155479 & 0.94 & 57.05 \\
\hline 7 & Hexadecanoic acid methyl ester & 24.676 & 1192974 & 1.26 & 485099 & 2.93 & 74.05 \\
\hline 8 & 1-Heptadecene & 26.030 & 311486 & 0.33 & 137699 & 0.83 & 57.05 \\
\hline 9 & $\begin{array}{c}(\mathrm{E}, \mathrm{E})-9,12 \text {-octadecadienoic acid, methyl } \\
\text { ester }\end{array}$ & 27.866 & 592188 & 0.62 & 241052 & 1.46 & 67.05 \\
\hline 10 & 10-Octadecenoic acid, methyl ester & 28.008 & 530171 & 0.56 & 140420 & 0.85 & 55.00 \\
\hline 11 & Methyl stearate & 28.493 & 289267 & 0.31 & 130754 & 0.79 & 74.05 \\
\hline 12 & Campesterol & 34.368 & 7179548 & 7.58 & 611633 & 3.70 & 130.10 \\
\hline 13 & 2-monopalmitoylglycerol & 34.974 & 4214578 & 4.45 & 1442175 & 8.72 & 98.10 \\
\hline 14 & Docosanoic acid, methyl ester & 35.241 & 274692 & 0.29 & 121450 & 0.73 & 74.05 \\
\hline 15 & Stigmasterol & 36.111 & 21637780 & 22.83 & 1578532 & 9.54 & 55.00 \\
\hline 16 & a-Monostearin & 38.076 & 745937 & 0.79 & 261504 & 1.58 & 98.10 \\
\hline 17 & B-Sitosterol & 38.833 & 12188664 & 12.86 & 1919681 & 11.60 & 55.05 \\
\hline 18 & Delta-8(14)-stigmastenol & 38.867 & 4444179 & 4.69 & 1865368 & 11.27 & 414.40 \\
\hline 19 & $\gamma$-Sitosterol & 38.974 & 18213558 & 19.22 & 2852026 & 17.23 & 55.05 \\
\hline 20 & 3-B-Cholest-5-en-3-ol, 24-propylidene & 39.380 & 3760112 & 3.97 & 697422 & 4.21 & 55.05 \\
\hline 21 & Cholest-4-en-3-one, 26-acetyloxy & 40.035 & 3666170 & 3.87 & 446784 & 2.70 & 124.10 \\
\hline 22 & Cycloartenol acetate & 40.718 & 3374761 & 3.56 & 448027 & 2.71 & 69.05 \\
\hline 23 & Delta-4-sitosterol-3-one & 43.340 & 3204726 & 3.38 & 501155 & 3.03 & 124.10 \\
\hline
\end{tabular}




\begin{tabular}{|c|c|c|c|c|c|c|c|}
\hline Peak & Name & Retention time & Area & $\begin{array}{c}\text { Area } \\
\text { (\%) }\end{array}$ & Height & Height (\%) & Base $(m / z)$ \\
\hline$\overline{1}$ & 2,4-Ditert-butylphenol & 15.577 & 5080233 & 8.88 & 1432098 & 8.98 & 191.2 \\
\hline 2 & 3-Heptadecanol & 22.235 & 600188 & 1.05 & 234753 & 1.47 & 59.05 \\
\hline 3 & $\begin{array}{c}\text { 2-Methyl-2-(4H-1,2,4-triazol-4-ylamino) } \\
\text { propanenitrile }\end{array}$ & 22.492 & 1692219 & 2.96 & 473617 & 2.97 & 124.1 \\
\hline 4 & Isopropyl myristate & 22.619 & 643946 & 1.13 & 206490 & 1.29 & 60 \\
\hline 5 & Neophytadiene & 22.899 & 3726755 & 6.51 & 1476272 & 9.26 & 68.05 \\
\hline 6 & Phytol acetate & 23.77 & 1251973 & 2.19 & 523506 & 3.28 & 82.1 \\
\hline 7 & (Z)-7-Hexadecenoic acid, methyl ester & 24.56 & 297630 & 0.52 & 134349 & 0.84 & 57.05 \\
\hline 8 & Hexadecanoic acid methyl ester & 24.68 & 2628617 & 4.59 & 1107727 & 6.95 & 74.05 \\
\hline 9 & E-15-Heptadecenal & 26.037 & 488789 & 0.85 & 214456 & 1.34 & 57.05 \\
\hline 10 & 9,12-Octadecadienoic acid methyl ester & 27.87 & 845084 & 1.48 & 328977 & 2.06 & 67.05 \\
\hline 11 & $\begin{array}{c}(\mathrm{Z}, \mathrm{Z}, \mathrm{Z})-9,12,15-\text { Octadecatrienoic acid methyl } \\
\text { ester }\end{array}$ & 27.981 & 1425963 & 2.49 & 416132 & 2.61 & 79.1 \\
\hline 12 & Phytol & 28.199 & 4248618 & 7.43 & 1659589 & 10.41 & 71.05 \\
\hline 13 & Eicosane & 28.403 & 411563 & 0.72 & 158432 & 0.99 & 57.05 \\
\hline 14 & Methyl stearate & 28.498 & 824697 & 1.44 & 359533 & 2.25 & 74.05 \\
\hline 15 & 1-Heneicosanol & 29.729 & 263909 & 0.46 & 123012 & 0.77 & 57.05 \\
\hline 16 & $\begin{array}{l}\text { Formamide, } \mathrm{N}-\{4-[2-(1,1-\text { dimethylethyl)-5- } \\
\text { oxo-1,3-dioxolan-4-yl]butyl\} }\end{array}$ & 34.363 & 1411792 & 2.47 & 545830 & 3.42 & 130.1 \\
\hline 17 & Hexanoic acid pentadecyl ester & 34.667 & 1359889 & 2.38 & 153897 & 0.96 & 117.1 \\
\hline 18 & 2-Monopalmitoylglycerol & 34.983 & 11311798 & 2.38 & 3336569 & 20.92 & 98.1 \\
\hline 19 & Stigmasterol & 35.86 & 5789844 & 10.12 & 620446 & 3.89 & 55.05 \\
\hline 20 & B-monolinolein & 37.613 & 784256 & 1.37 & 249656 & 1.57 & 67.05 \\
\hline 21 & a-Glyceryl linolenate & 37.732 & 2227656 & 3.89 & 354042 & 2.22 & 55.05 \\
\hline 22 & Octadecanoic acid 2,3-dihydroxypropyl ester & 38.073 & 2561676 & 4.48 & 950686 & 5.96 & 98.1 \\
\hline 23 & $\gamma$-sitosterol & 38.697 & 7333765 & 12.82 & 889072 & 5.57 & 55.05 \\
\hline
\end{tabular}

in butanol extract were considered to be phenol-2,4bis(1,1-dimethylethyl), (e)-9-octadecene, 3-hydroxybeta-damascone. Whereas in the methanol extract, the major compounds identified were, 2,4-ditertbutylphenol, 3-heptadecanol and 2-methyl-2-(4h1,2,4-triazol-4-ylamino) propanenitrile. The GC-MS chromatograms of both extracts are shown in figs. 4A and $\mathrm{B}$.

GC-MS analysis of butanol and methanol extracts revealed the existence of various compounds like phenolic compounds (phenol-2,4-bis(1,1dimethylethyl) and 2,4-ditert-butylphenol), sterols (campesterol, stigmasterol, $\beta$-sitosterol, delta-8(14)stigmasterol, $\gamma$-sitosterol, delta-4-sitosterol-3-one, stigmasterol, $\beta$-monolinolein and $\gamma$-sitosterol), alcoholic compounds(2-monopalmitoylglycerol,3-heptadecanol, phytol, 1-heneicosanol and 2-monopalmitoylglycerol) and easters (hexadecanoic acid methyl ester, (e,e)-9, 12-octadecadienoic acid methyl ester, 10-octadecenoic acid methyl ester, docosanoic acid methyl ester, 7-hexadecenoic acid, (Z)-methyl ester, hexadecanoic acid methyl ester, 9,12-octadecadienoic acid methyl ester, (Z,Z,Z)-9,12,15-octadecatrienoic acid methyl ester, hexanoic acid pentadecyl ester, octadecanoic acid-2,3-dihydroxypropyl ester). Stigmasterol, sitosterol, phytol, and hexadecanoic acid were the major compounds present in different quantities both in butanol and methanol extracts. Phytol is a precursor of vitamin $\mathrm{K}$ and $\mathrm{E}$, which exhibits potent antioxidant, cytotoxic and antinociceptive activity ${ }^{[34-37]}$. Phytosterols such as stigmasterol, $\beta$-sitosterol and $\gamma$-sitosterol showed antiinflammatory action by blocking the inflammatory cytokines and inducing apoptosis. Sterols even possessed anticancer and antioxidant properties. Sterols prevented angiogenesis by enhancing antioxidant enzymes and blocked the release of ROS and prevented oxidative stress ${ }^{[38,39]}$. Phenolic compounds exhibited antiinflammatory properties and their mechanism of action was reported to be similar to that of nonsteroidal antiinflammatory drugs. Besides COX enzyme inhibition, phenolic compounds also inhibited other pro-inflammatory mediators and their activity through gene suppression. Some phenolic compounds in inflammatory and antioxidant pathways can up/downregulate the transcriptional factors like 


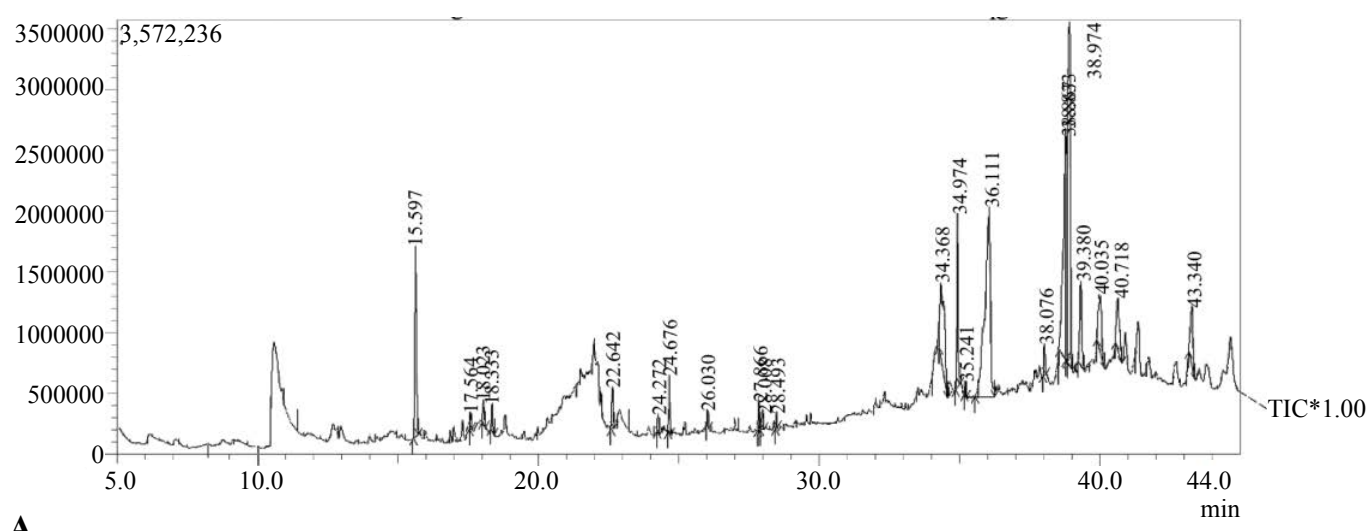

A

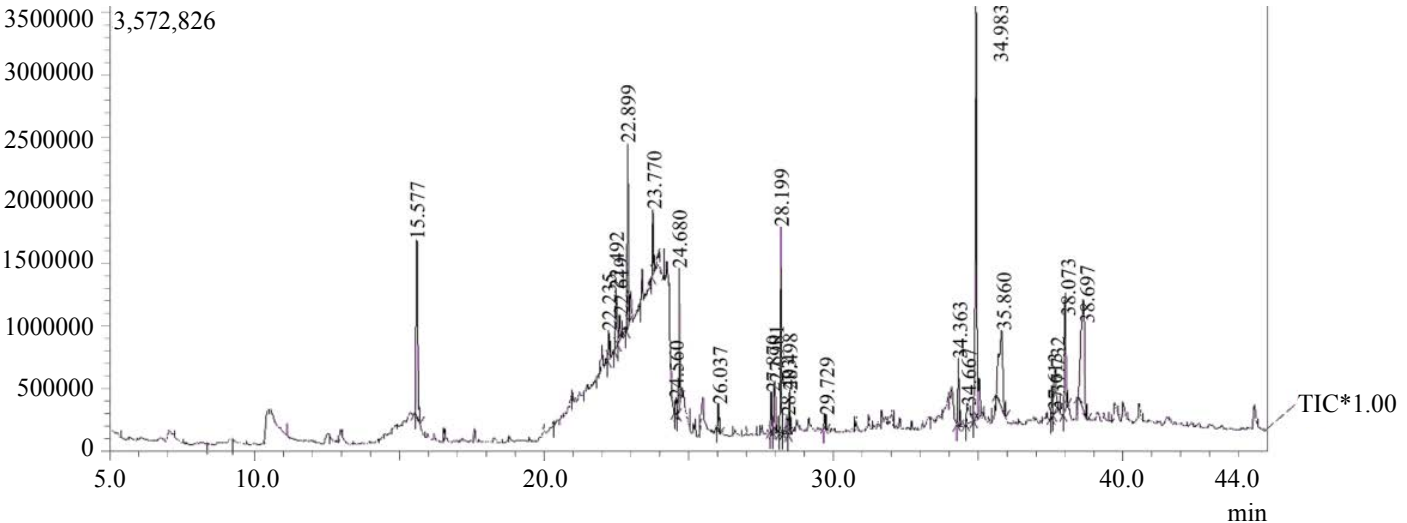

B

Fig. 4: GC-MS chromatogram of butanol and methanol extract of Acacia auriculiformis GC-MS chromatogram of (A) butanol and (B) methanol extract of leaves of Acacia auriculiformis

nuclear factor-kB or $\mathrm{Nrf}-2^{[32]}$. On the basis of the above-reported evidence, it could be summarised that the compounds identified through GC-MS analysis possessed pharmacological significance indicating the antioxidant and antiinflammatory potential of the plant A. auriculiformis.

The methanol and butanol extracts were able to significantly scavenge the free radicals and reduce inflammation. This confirmed the justification of the traditional use and efficacy of this plant to treat many free radical-born and inflammatory-related major diseases. The GC-MS analysis of butanol and methanol extracts revealed the presence of various sterols and phenolic compounds, which might be responsible for imparting the antiinflammatory as well as antioxidant action. The separation and characterization of these bioactive phytoconstituents from the methanol and butanol extracts responsible for the in vitro antioxidant scavenging and in vivo antiinflammatory activities are currently under progress.

\section{Acknowledgments:}

The authors would like to acknowledge UGCBSR (Award Letter No. F.25-1/2013-14(BSR)/7-
36/2007(BSR)) for financially supporting the study. The authors would also like to thank Birla Institute of Technology, Mesra, Ranchi for providing necessary laboratory facilities including animal house facilities and Kerala Forest Research Institute, Peechi, Thrissur for providing access to GC-MS instrumentation facility. The authors would also like to acknowledge Dr. V. P. Prasad, Senior Principal Scientist-D, Botanical Survey of India, Kolkata India for identifying the plant material.

\section{Conflict of interest:}

The authors declare no conflict of interest.

\section{REFERENCES}

1. Oyedapo OA, Adewunmi CO, Iwalewa EO, Makanju VO. Analgesic, antioxidant and anti-inflammatory related activities of 21-hydroxy-2, 41-dimethoxychalcone and 4-hydroxychalcone in mice. J Biol Sci 2008;8(1):131-6.

2. Dinarello CA. Anti-inflammatory agents: present and future. Cell 2010;140(6):935-50.

3. Anilkumar M. Ethnomedicinal plants as anti-inflammatory and analgesic agents. In: Chattopadhyay D, editor. Ethnomedicine: A source of complementary therapeutics 2010. p. 267-93.

4. Gadamsetty G, Maru S, Sarada NC. Antioxidant and antiinflammatory activities of the methanolic leaf extract of 
traditionally used medicinal plant Mimusops elengi L. J Pharm Sci Res 2013;5(6):125-30.

5. Cui XY, Kim JH, Zhao X, Chen BQ, Lee BC, Pyo HB, et al. Antioxidative and acute anti-inflammatory effects of Campsis grandiflora flower. J Ethnopharmacol 2006;103(2):223-8.

6. Girijashankar V. Micropropagation of multipurpose medicinal tree Acacia auriculiformis. J Med Plants Res 2011;5(3):462-6.

7. Kaur K, Arora S, Hawthorne ME, Kaur S, Kumar S, Mehta RG. A correlative study on antimutagenic and chemopreventive activity of Acacia auriculiformis A. Cunn. and Acacia nilotica (L.) Willd. Ex Del. Drug Chem Toxicol 2002;25:39-64.

8. Dhar ML, Dhar MM, Dhawan BN, Mehrotra BN, Ray C. Screening of Indian plants for biological activity. Indian J Exp Biol 1980;18:594-06.

9. Okokon JE, Jackson O, Opara $\mathrm{KN}$, Emmanuel E. In vivo antimalarial activity of ethanolic leaf extract of Acacia auriculiformis. Int J Drug Dev Res 2010;2:482-7.

10. Ghosh M, Babu SP, Sukul NC, Mahato SB. Antifilarial effect of two triterpenoid saponins isolated from Acacia auriculiformis. Indian J Exp Biol 1993;31:604-6.

11. Ghosh NK, Babu SS, Sukul NC, Ito A. Cestocidal activity of Acacia auriculiformis. J Helminthol 1996;70:171-2.

12. Mandal P, Babu SS, Mandal NC. Antimicrobial activity of saponins from Acacia auriculiformis. Fitoterapia 2005;76:462-5.

13. Singh R, Singh S, Kumar S, Arora S. Evaluation of antioxidant potential of ethyl acetate extract/fractions of Acacia auriculiformis A. Cunn. Food Chem Toxicol 2007;45:121623.

14. Pakrashi A, Ray H, Pal BC, Mahato SB. Sperm immobilizing effect of triterpene saponins from Acacia auriculiformis. Contraception 1991;43:475-83.

15. Singh SU, Sharma NI. Evaluation of wound healing activity of Acacia auriculiformis A. Cunn. Stem bark. Asian J Pharm Clin Res 2014;7:204-7.

16. Sathya A, Siddhuraju P. Protective effect of bark and empty pod extracts from Acacia auriculiformis against paracetamol intoxicated liver injury and alloxan induced type II diabetes. Food Chem Toxicol 2013;56:162-70.

17. SharmaN, SinghS, Singh SK. Review on Phytopharmacological Properties of Acacia auriculiformis A. Cunn. ex. Benth. Planta Activa 2016(1):1-6.

18. Pereira MA, Grubbs CJ, Barnes LH, Li H, Olson GR, Eto I, et al. Effect of the phytochemicals, curcumin and Quercetin upon azomethane-induced: cancer and 7,12-dimethylbenz(a) anthracene-induced mammary cancer in rats. Carcinogenesis 1996;17:1305-11.

19. Yang CS, Kim S, Yang GY, Lee MJ, Liao J, Chung JY, et al. Inhibition of the carcinogenesis by tea; bioavailability of the tea polyphenols and mechanisms of the action. Proc Soc Exp Biol Med 1999;220:213-7.

20. Harbone JB. Phytochemical methods. London, New York: Chapman and Hall; 1998. p. 160-78.

21. Kant K, Walia M, Agnihotri VK, Pathania V, Singh B. Evaluation of antioxidant activity of Picrorhiza kurroa (leaves) extracts. Indian J Pharm Sci 2013;75(3):324.

22. Dey S, Ghosh M. A LC/MS-MS Guided Isolation of Laccaic Acid-A: A Potent Antimicrobial Agent. Indian J Pharm Educ Res 2018;52(4):S287-95.

23. Guideline TT, Guideline O. OECD Guidelines for the Testing of Chemicals. 2001. Available from: https://www.oecd.org/ chemicalsafety/testing/44098118.pdf.

24. Vogel HG, Vogel WH. Drug discovery and evaluation: Pharmacological assays. Springer-Verlag Berlin Heidelberg; 2013. p. 757-60.

25. Chau TT. Pharmacological Methods in the Control of Inflammations. Analgesic testing in animal models. New York: Alan R Liss Inc; 1989. p. 195-212.

26. Sakihama Y, Cohen MF, Grace SC, Yamasaki H. Plant phenolic antioxidant and prooxidant activities: phenolicsinduced oxidative damage mediated by metals in plants. Toxicology 2002;177(1):67-80.

27. Perianayagam JB, Sharma SK, Pillai KK. Anti-inflammatory activity of Trichodesma indicum root extract in experimental animals. J Ethnopharmacol 2006;104(3):410-4.

28. Hamburger M, Hostettmann K. Bioactivity in plants: the link between phytochemistry and medicine. Phytochemistry 1991;30(12):3864-74.

29. Anosike CA, Obidoa O, Ezeanyika LU. Membrane stabilization as a mechanism of the anti-inflammatory activity of methanol extract of garden egg (Solanum aethiopicum). Daru 2012;20(1):76.

30. Selvam C, Jachak SM. A cyclooxygenase (COX) inhibitory flavonoids from the seeds of Semecarpus anacardium. J Ethnopharmacol 2004;95(2-3):209-12.

31. Sokeng SD, Koubé J, Dongmo F, Sonnhaffouo S, Nkono BL, Taïwé GS, et al. Acute and chronic anti-inflammatory effects of the aqueous extract of Acacia nilotica (L.) Del.(Fabaceae) pods. Acad J Med Plants 2013;1(1):1-5.

32. Dongmo AB, Nguelefack T, Lacaille-Dubois MA. Antinociceptive and anti-inflammatory activities of Acacia pennata wild (Mimosaceae). J Ethnopharmacol 2005;98 (1-2):201-06.

33. Bukhari IA, Khan AR, Gilani HA, Ahmed S, Saeed AS. Analgesic, antiinflammatory and anti-platelet activities of the methanolic extract of Acacia modesta leaves. Inflammopharmacology 2010;18(4):187-96.

34. Santos CC, Salvadori MS, Mota VG, Costa LM, de Almeida AA, de Oliveira GA, et al. Antinociceptive and antioxidant activities of phytol in vivo and in vitro models. Neurosci J 2013;2013:949452.

35. Pejin B, Savic A, Sokovic M, Glamoclija J, Ciric A, Nikolic M, et al. Further in vitro evaluation of antiradical and antimicrobial activities of phytol. Nat Prod Res 2014;28(6):372-76.

36. Ogunlesi M, Okiei W, Ofor E, Osibete AE. Analysis of the essential oil from the dried leaves of Euphorbia hirta Linn (Euphorbiaceae), a potential medication for asthma. Afr J Biotechnol 2009;8(24):7042-50.

37. Satyal P, Dosoky NS, Poudol A, Setzer, WN. Essential oil constituents and their biologic activities from the leaves of Cassia fistula growing in Nepal. J Med Aromat Plants 2012;3(2):1-4.

38. Woyengo TA, Ramprasath VR, Jones PJ. Anticancer effects of phytosterols. Eur J Clin Nutr 2009;63(7):813-20.

39. Imanaka H, Koide H, Shimizu K, Asai T, Kinouchi Shimizu $\mathrm{N}$, Ishikado A, et al. Chemoprevention of tumor metastasis by liposomal beta-sitosterol intake. Biol Pharm Bull 2008;31(3):400-4. 